\title{
Large, Highly Modular Narrow-Gap Electrolytic Flow Cell and Application in Dehydrogenative Cross- Coupling of Phenols
}

Barbara Gleedeł, Maximilian Seltł, Christoph Gütz, Andreas Stenglein, Siegfried R. Waldvogel*

aInstitute of Organic Chemistry, Johannes Gutenberg-University Mainz, Duesbergweg 10-14, D55128 Mainz, Germany; Email: waldvogel@uni-mainz.de;

Supporting Information 


\section{Table of Content}

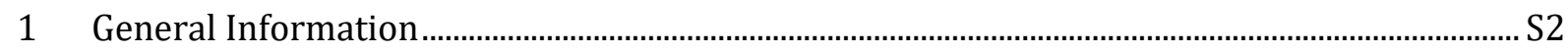

2 Cell Design: Technical Drawings of the $4 \mathrm{~cm} \times 12 \mathrm{~cm}$ Flow Cell ..................................................... 3

3 General Protocol for the Cross-Coupling Reactions in a Flow Cell ..............................................S10

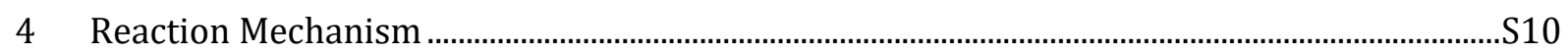

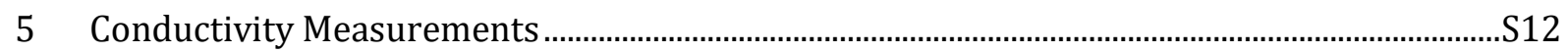

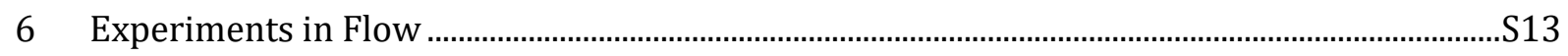

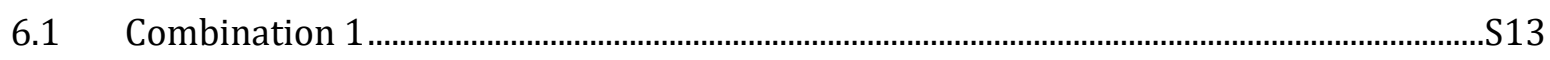

6.1.1 Screening of Supporting Electrolyte ...............................................................................

6.1.2 Screening of Concentration and Ratio of the Starting Material ....................................S14

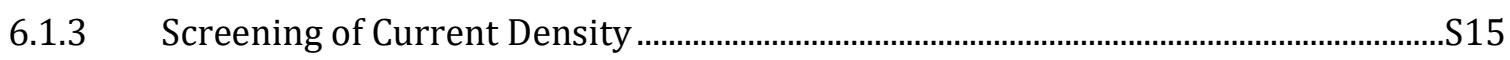

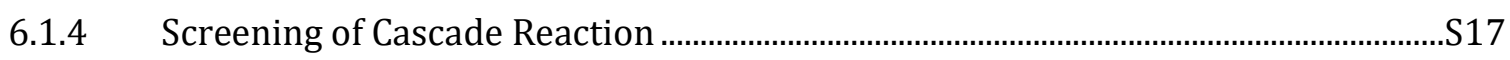

$6.2 \quad$ Combination 2

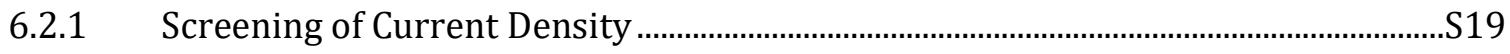

6.2.2 Screening of Cascade Reaction ..................................................................................... 20

6.2.3 Screening of Electrode Distance ………........................................................................... 21

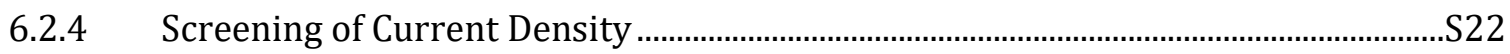

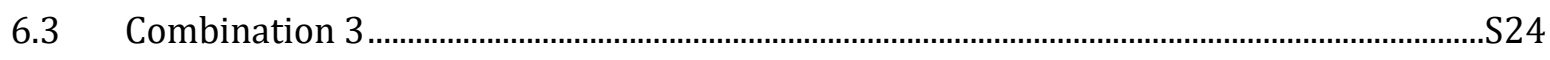

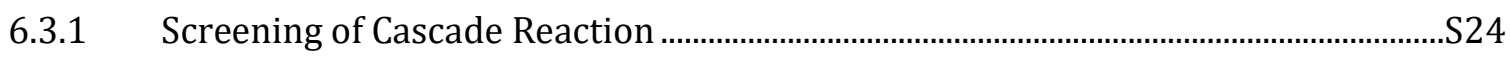

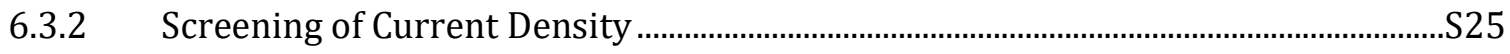

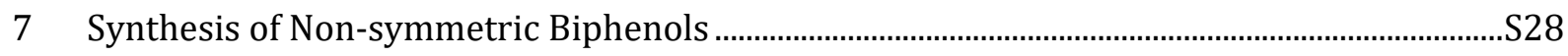

7.1 2,2'-Dihydroxy-3-methoxy-3',5,5'-trimethylbiphenyl ..........................................................S28

7.2 2'4-Dihydroxy-3,5-dimethoxy-5'-tert-butylbiphenyl ............................................................. 229

7.3 Methyl 3-hydroxy-4-(4'-hydroxy-3',5'-dimethoxyphenyl)-2-naphthoate .........................S30

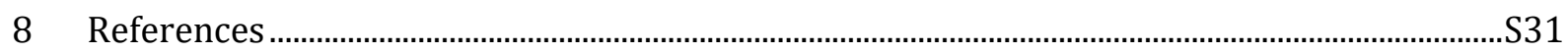




\section{General Information}

All of the reagents used were analytical-grade. Solvents were purified by standard methods. ${ }^{1}$ As supporting electrolyte $\mathrm{N}$-methyl- $\mathrm{N}, \mathrm{N}, \mathrm{N}$-tributylammonium methylsulfate (kindly provided by BASF SE, Ludwigshafen, Germany) was used. For electrochemical reactions, boron-doped diamond (15 $\mu \mathrm{m}$ diamond layer on silicon) was applied. BDD electrodes (DIACHEM ${ }^{\mathrm{TM}}$ ) were obtained from CONDIAS (Itzehoe, Germany).

Conductivity measurements were performed with a 856 Conductivity Module (Metrohm AG, Herisau, Switzerland) using a conductivity measuring cell $6.0915 .100 \mathrm{Pt} 1000 / \mathrm{B} / 2 \quad 0 \ldots 70{ }^{\circ} \mathrm{C}$ (Metrohm AG, Herisau, Switzerland) and for PC control software tiamo 2.4 (Metrohm AG, Herisau, Switzerland).

Column chromatography was performed on silica gel $60 \mathrm{M}(0.040-0.063 \mathrm{~mm}$, Macherey-Nagel GmbH\&Co, Düren, Germany) with a maximum pressure of 1.6 bar. As eluents mixtures of cyclohexane and ethyl acetate were used. Silica gel 60 sheets on aluminum (F254, Merck, Darmstadt, Germany) were employed for thin layer chromatography.

Gas chromatography was performed on a Shimadzu GC-2010 (Shimadzu, Japan) using a ZB-5 column (Phenomenex, USA; length: $30 \mathrm{~m}$, inner diameter: $0.25 \mathrm{~mm}$, film: $0.25 \mathrm{~mm}$, carrier gas: hydrogen). GC-MS measurements were carried out on a Shimadzu GC-2010 (Shimadzu, Japan) using a ZB-5 column (Phenomenex, USA; length: $30 \mathrm{~m}$, inner diameter: $0.25 \mathrm{~mm}$, film: $0.25 \mathrm{~mm}$, carrier gas: hydrogen). The method was coupled with mass spectrometry on a Shimadzu GCMSQP2010.

Melting points were determined with a Melting Point Apparatus B-545 (Büchi, Flawil, Switzerland) and were uncorrected. Heating rate: $2^{\circ} \mathrm{C} / \mathrm{min}$.

Spectroscopy and spectrometry: ${ }^{1} \mathrm{H}$ NMR spectra were recorded at $25{ }^{\circ} \mathrm{C}$ by using a Bruker Avance III HD 400 (400 MHz) or (5 mm BBFO-SmartProbe with $\mathrm{z}$ gradient and ATM, SampleXPress 60 sample changer, Analytische Messtechnik, Karlsruhe, Germany). Chemical shifts $(\delta)$ are reported in parts per million (ppm) relative to TMS as internal standard or traces of $\mathrm{CHCl}_{3}$ in the corresponding deuterated solvent. Mass spectra are obtained by using a MAT 95 (Finnigan, Germany) apparatus employing FD. 


\section{Cell Design: Technical Drawings of the $4 \mathrm{~cm} \times 12 \mathrm{~cm}$ Flow Cell}

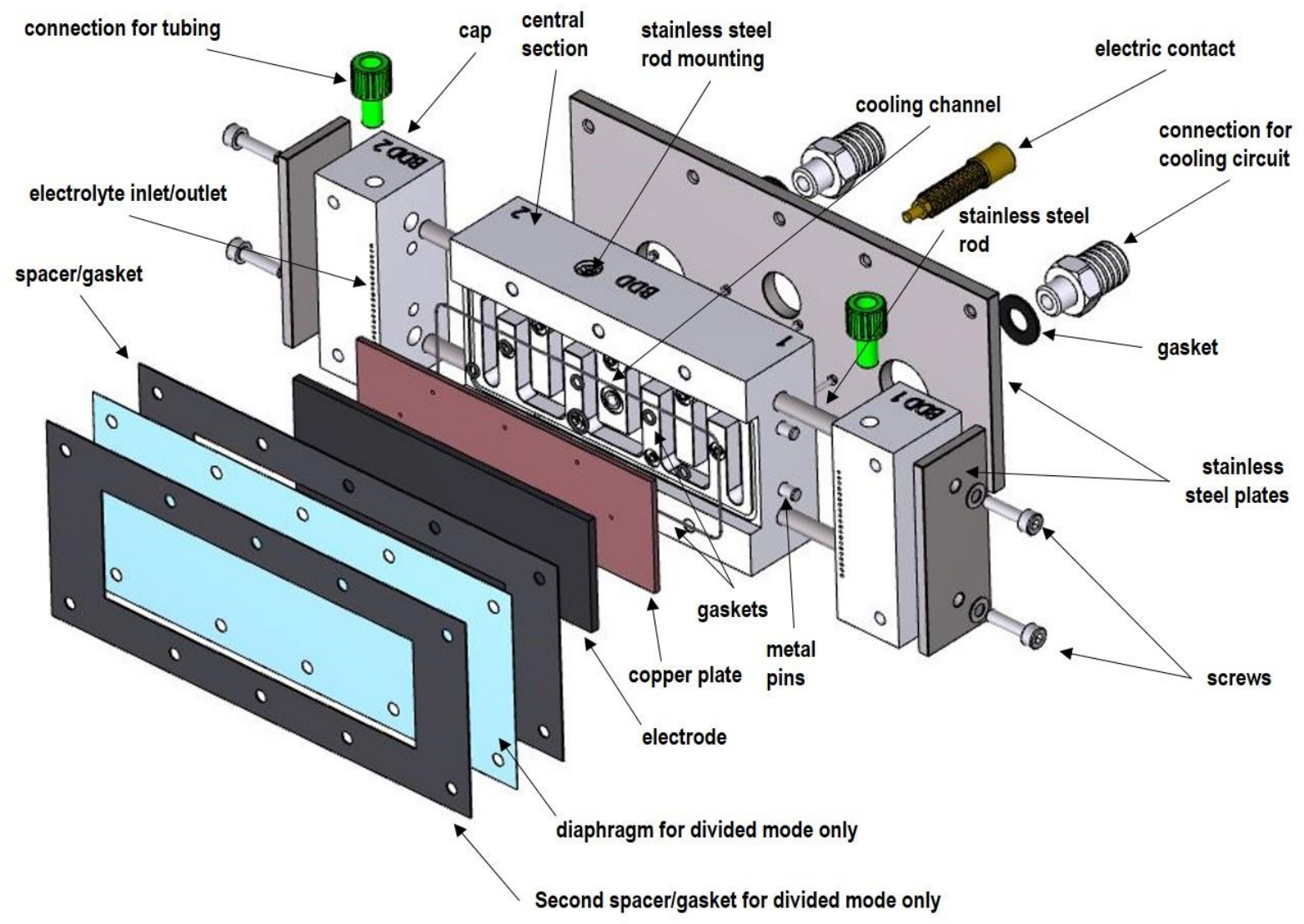

Figure S 1. Explosion drawing of one half-cell. The second spacer and the membrane are only necessary if the cell is run in divided mode. 


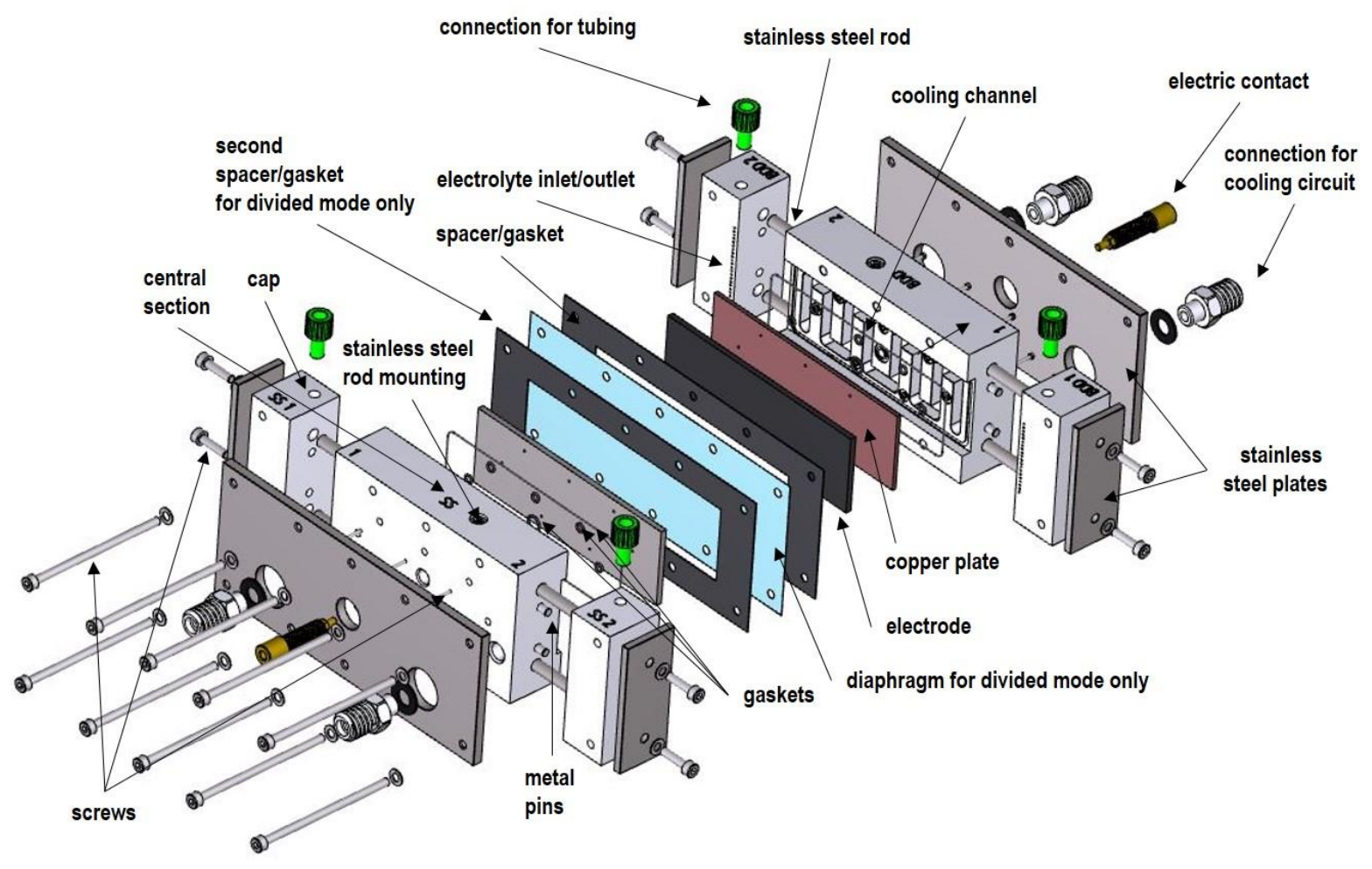

Figure S 2. Explosion drawing of the full $4 \mathrm{~cm} \times 12 \mathrm{~cm}$ flow cell. The second spacer and the membrane are only necessary if the cell is run in divided mode. 

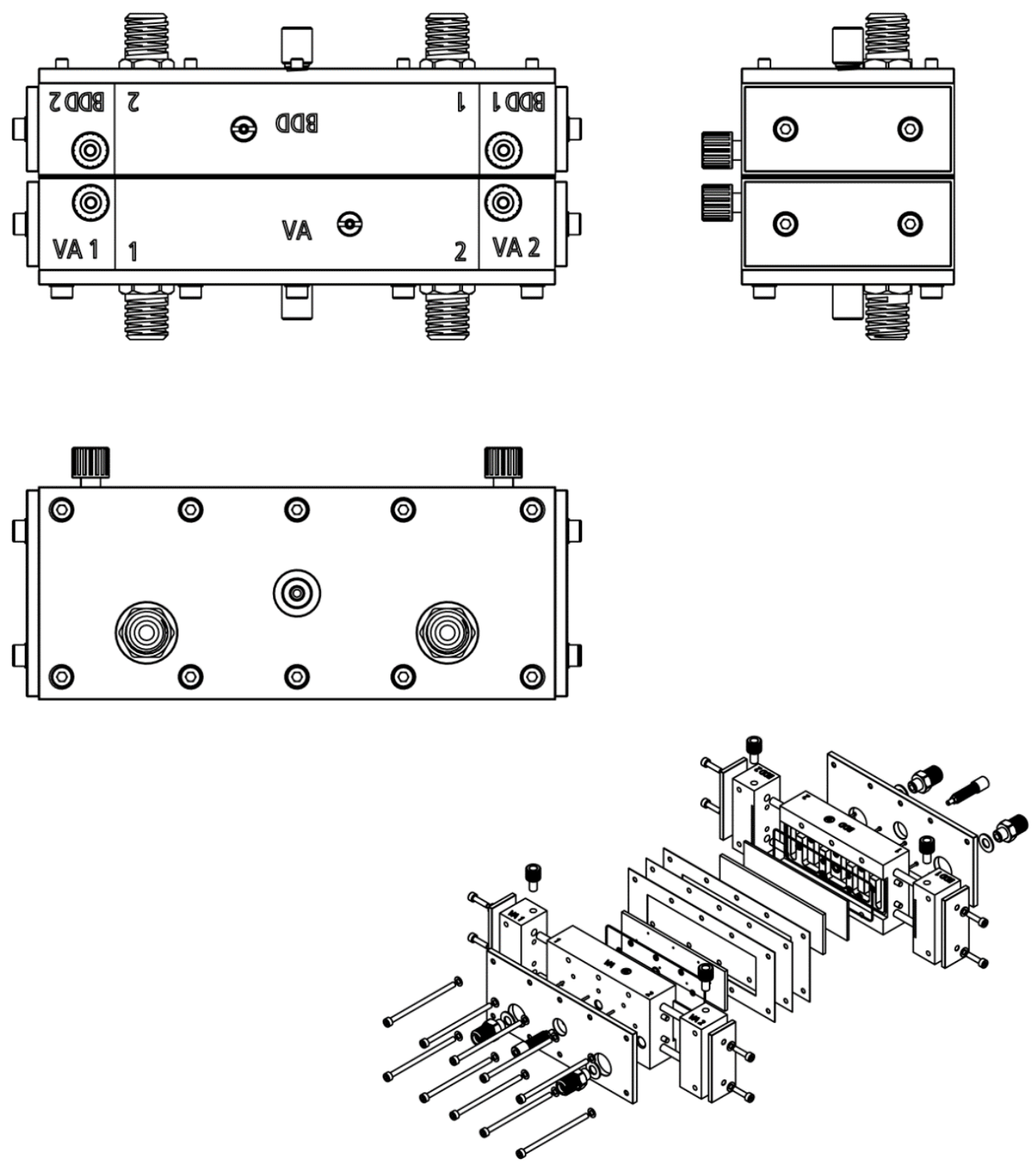

Figure $S 3$. Technical drawing of the mounted $4 \mathrm{~cm} \times 12 \mathrm{~cm}$ flow cell and explosion drawing of the $4 \mathrm{~cm} \times 12 \mathrm{~cm}$ flow cell. 


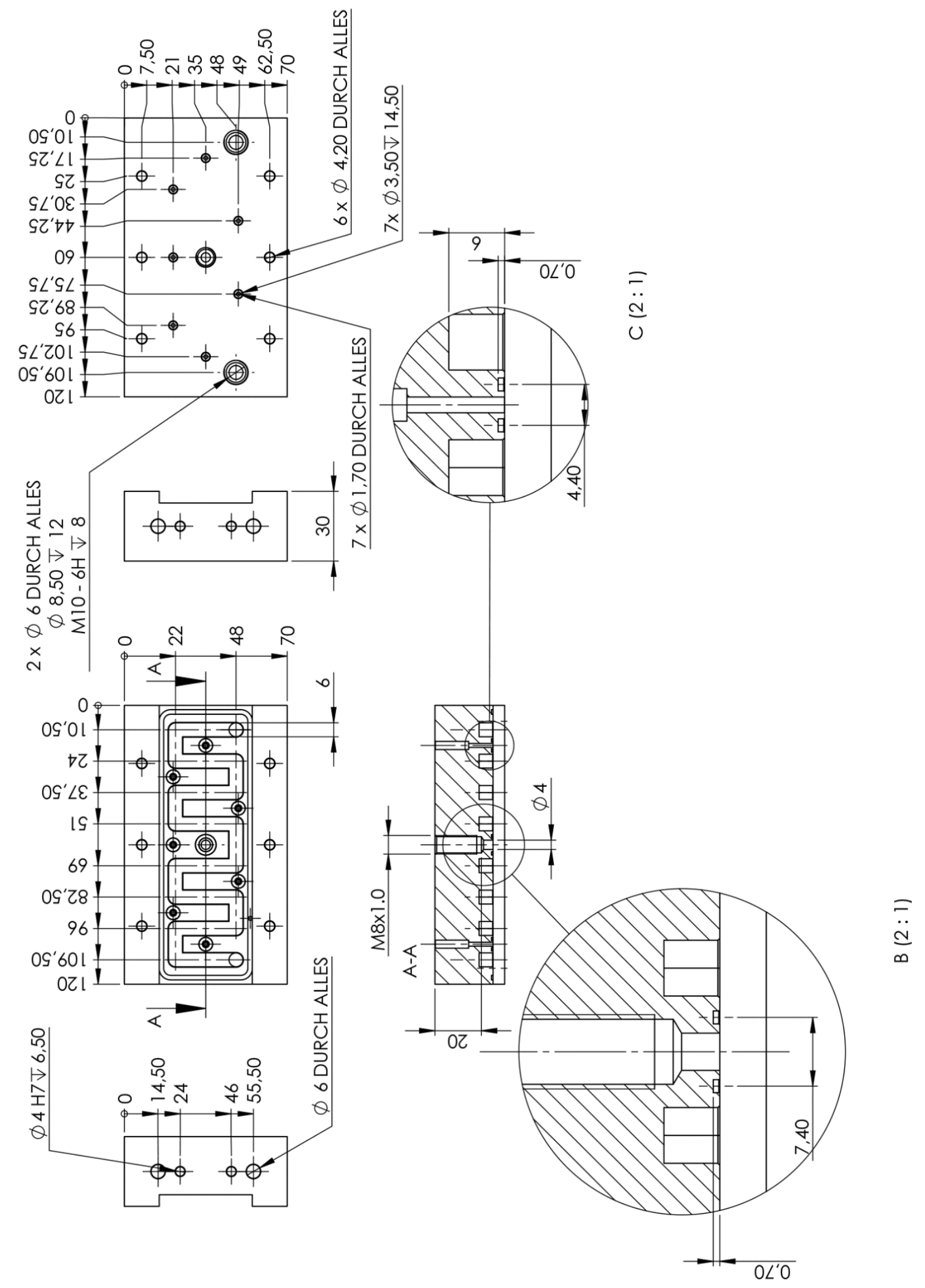

Figure S 4. Technical drawing of the Teflon pieces. All numbers in $\mathrm{mm}$. 

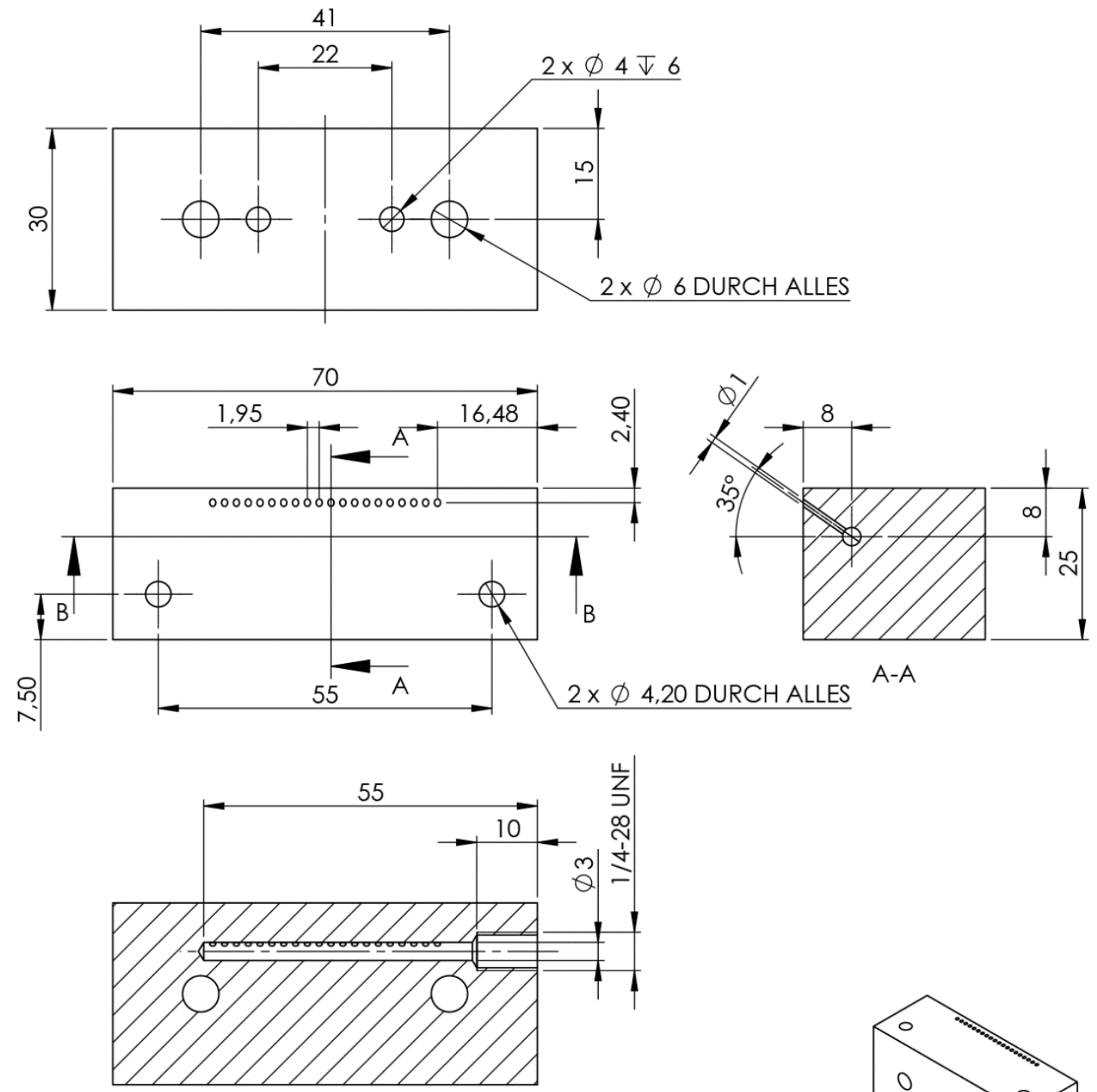

B-B

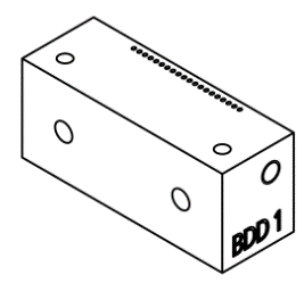

Figure $S 5$. Technical drawing of the Teflon caps. All numbers in $\mathbf{m m}$. 


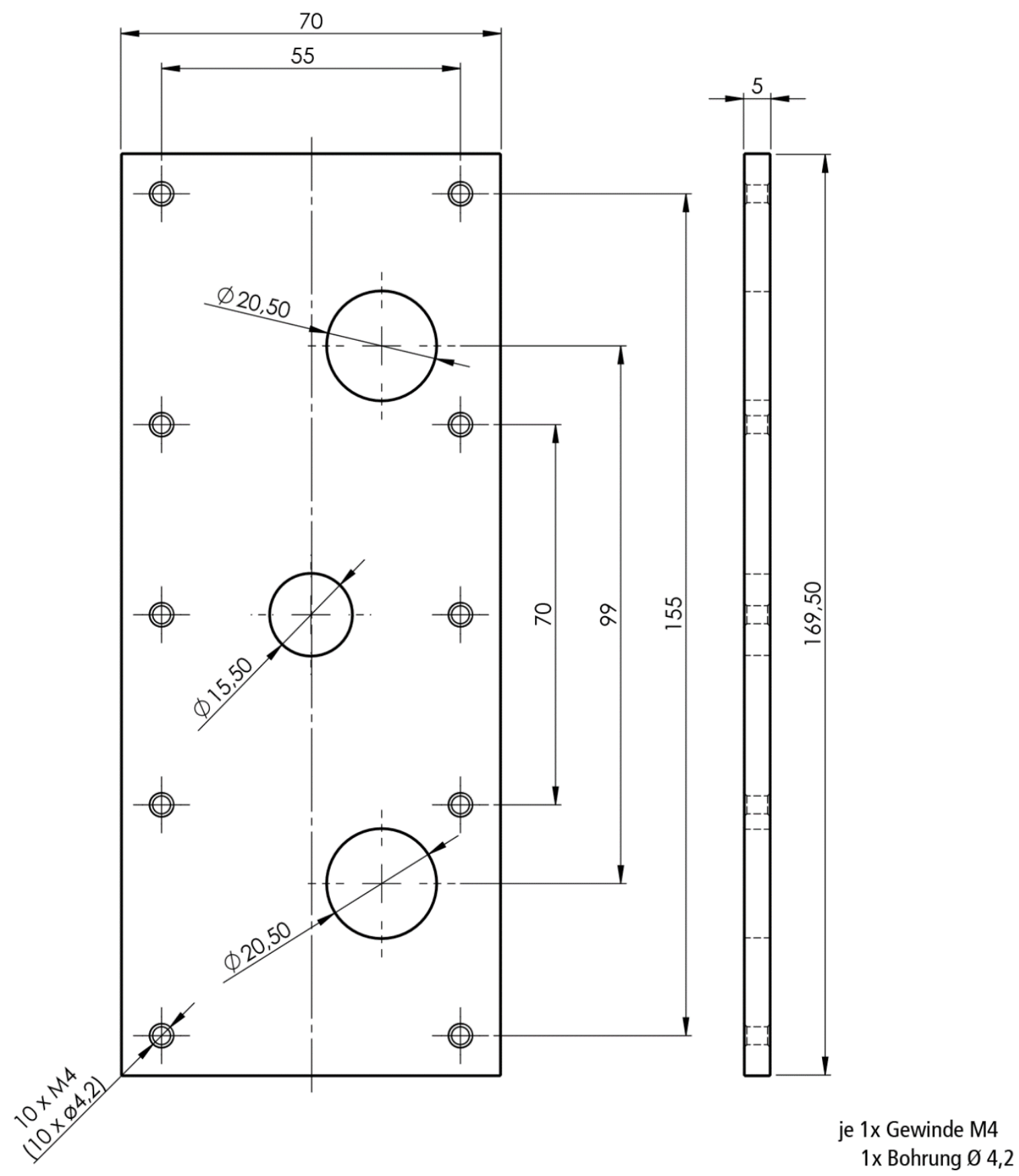

Figure S 6. Technical drawing of the stainless steel plates. All numbers in $\mathbf{m m}$. 

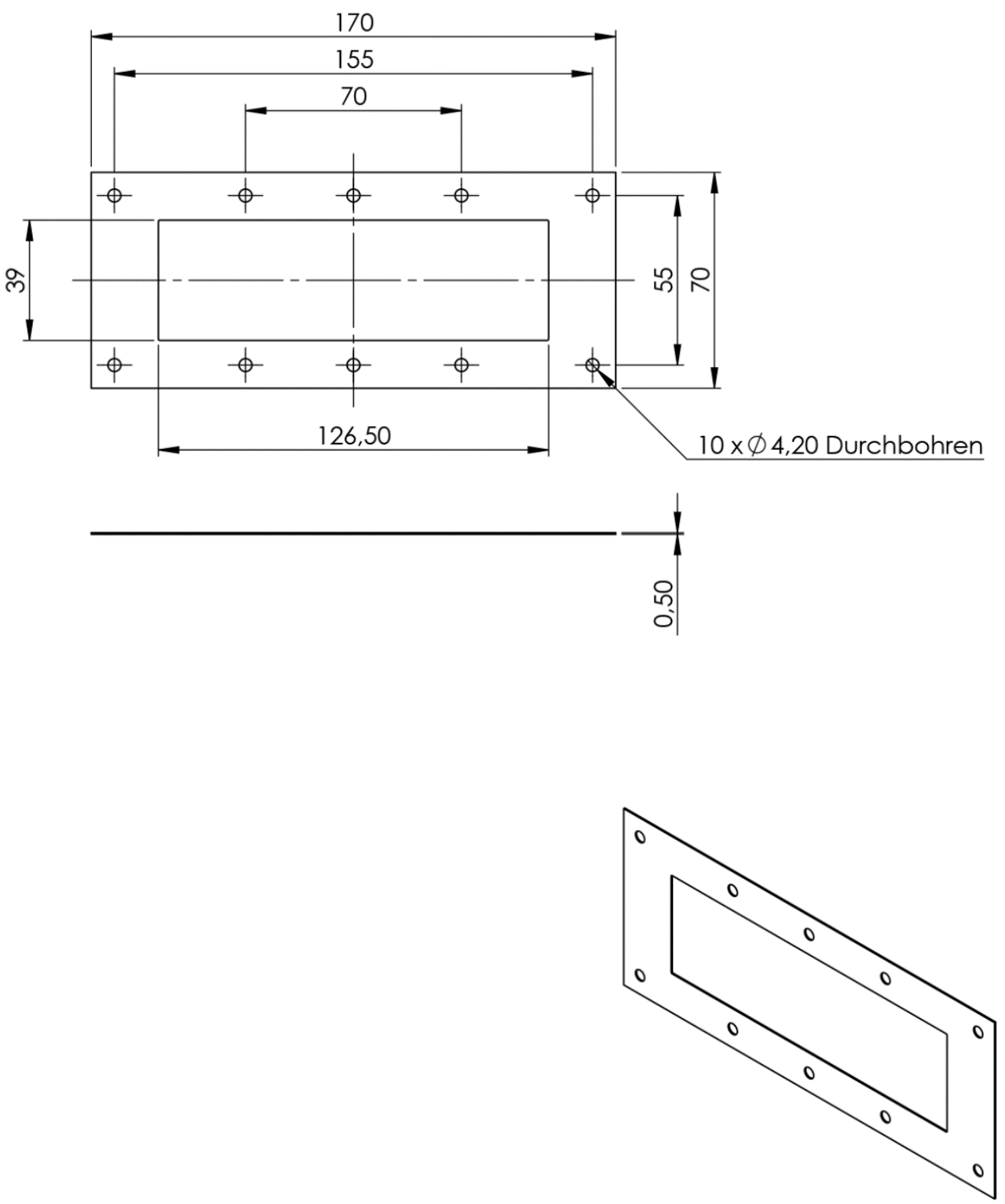

Figure $S$ 7. Technical drawing of the EPDM spacer. All numbers in $\mathbf{m m}$. 


\section{General Protocol for the Cross-Coupling Reactions in a Flow Cell}

Both phenol components were dissolved in a solution of HFIP or HFIP with 18 vol \% methanol and $\mathrm{MeBu}_{3} \mathrm{NO}_{3} \mathrm{SOMe}$. The solution was pumped through the electrochemical flow cell. The corresponding electrochemical parameters were applied during electrolysis. After electrolysis the solvent was removed under reduced pressure, and the residue was prepared for internal standard procedure for gas chromatography measurements or purified by column chromatography and dried under reduced pressure to obtain the desired product.

\section{Reaction Mechanism}

The first step of the mechanistic sequence (Scheme S 1) of this reaction is, that the oxidation partner with lower oxidation potential $\mathbf{A}$ is oxidized at the boron-doped diamond (BDD) anode to form the phenoxyl radical I. This highly reactive radical intermediate is being attacked nucleophilic by the second coupling partner $\mathbf{B}$ and forms intermediate II. Intermediate II undergoes another one-electron oxidation at the BDD anode and extrudes a proton with a following rearomatization. Thereby, the desired non-symmetric biphenol $\mathbf{A B}$ is obtained. 


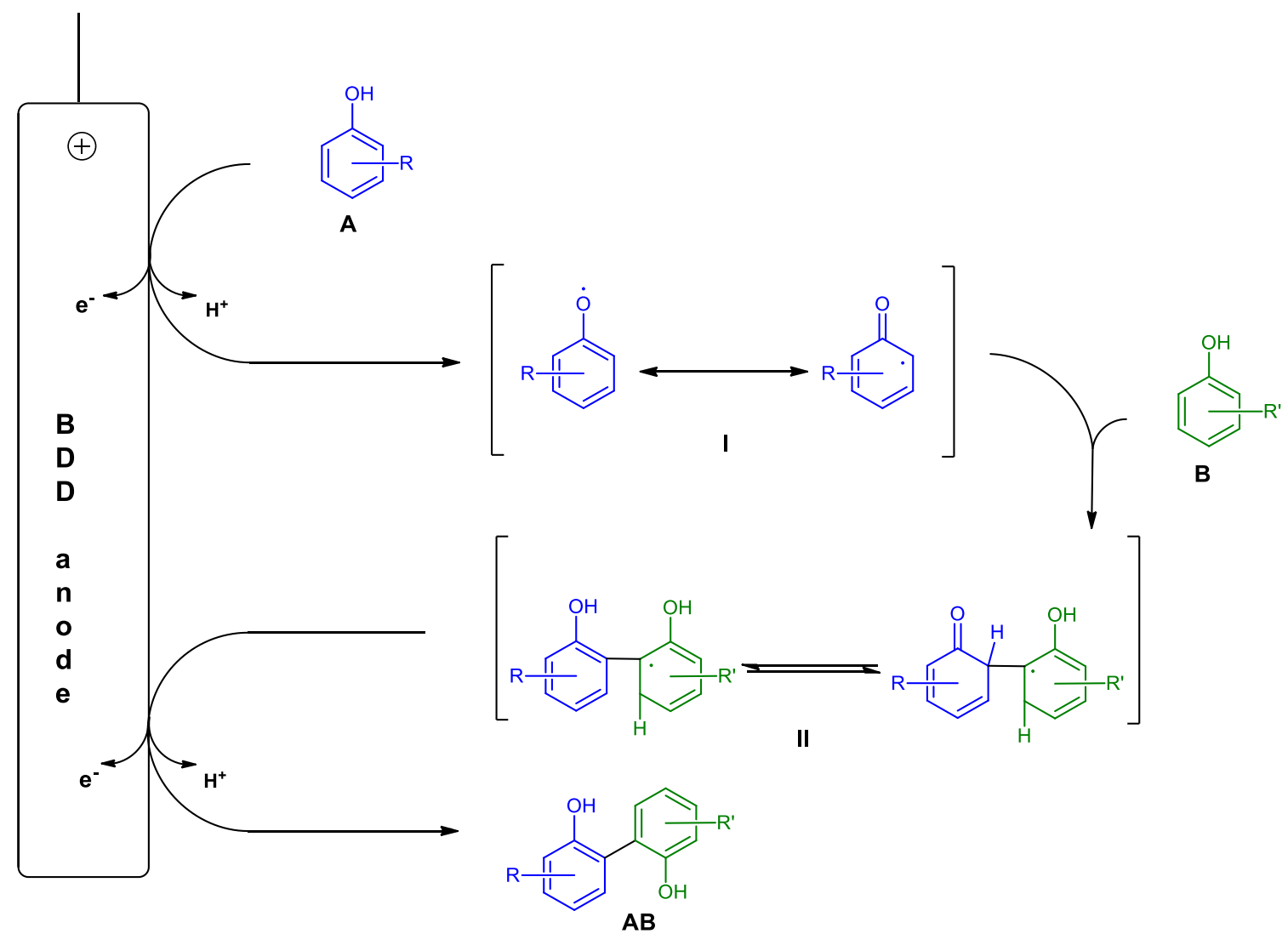

Scheme S 1: Postulated reaction mechanism of anodic C,C-cross-coupling reaction of phenols. ${ }^{2}$ 


\section{Conductivity Measurements}

\section{Calibration}

For the calibration of the conductivity measuring cell the cell constant $c$ was determined. Therefore, the conductivity $\kappa_{\text {measured }}$ of a $0.1 \mathrm{M}$ aqueous $\mathrm{KCl}$ solution was measured at $20{ }^{\circ} \mathrm{C}$ and compared to the theoretical conductivity of a $0.1 \mathrm{M}$ aqueous $\mathrm{KCl}$ solution $\kappa_{\text {theo }}$ :

$$
c=\frac{\kappa_{\text {theo }}^{K C l}}{\kappa_{\text {measured }}^{K C l}}=\frac{11.67 \mathrm{mS} / \mathrm{cm}}{16.80 \mathrm{mS} / \mathrm{cm}}=0.6905 .
$$

Then, the conductivities of each electrolyte solution ( $\kappa_{\text {measured }}^{e l}$ ) was measured. The conductivity related to the cell constant $\left(\kappa_{r e l}^{e l}\right)$ was calculated as

$$
\kappa_{\text {rel }}^{e l}=\kappa_{\text {measured }}^{e l} \cdot c
$$

Table S 1. Conductivity of the used electrolyte solutions.

\begin{tabular}{|l|c|c|}
\hline \multicolumn{1}{|c|}{ electrolyte solution } & $\kappa_{\text {measured }}^{\text {el }} \mathbf{S} \cdot \mathbf{m}^{-\mathbf{1}}$ & $\boldsymbol{\kappa}_{\text {rel }}^{\text {el }} \mathbf{~ S \cdot \mathbf { m } ^ { - 1 }}$ \\
\hline 0.005 M MTBS in HFIP & 0.0122 & 0.0085 \\
\hline 0.005 M MTBS in HFIP + 18 vol \% MeOH & 0.0142 & 0.0098 \\
\hline $\begin{array}{l}\text { 0.005 M MTBS, 0.15 M 2,6-dimethoxyphenol and } \\
0.45 \text { M methyl 3-hydroxynaphthoate in HFIP }\end{array}$ & 0.0093 & 0.0064 \\
\hline $\begin{array}{l}\text { 0.005 M MTBS, 0.15 M 2,6-dimethoxyphenol and } \\
0.45 \text { M 4-tert-butylphenol in HFIP }\end{array}$ & 0.0083 & 0.0057 \\
\hline $\begin{array}{l}\text { 0.005 M MTBS, 0.15 M 4-methylguaiacol and } \\
0.45 \text { M 2,4-dimethylphenol in HFIP + 18 vol \% MeOH }\end{array}$ & 0.0116 & 0.0080 \\
\hline
\end{tabular}




\section{Experiments in Flow}

For this manuscript, extensive experiments were performed on various parameters for the transfer to the flow cell of the anodic cross-coupling of phenols. This was not explained in detail in the manuscript, since not all screenings led to an optimization of the yield. However, these results are presented completely in the following:

\subsection{Combination 1}<smiles>COc1cc(C)ccc1O</smiles>

1<smiles>Cc1ccc(O)c(C)c1</smiles>

2

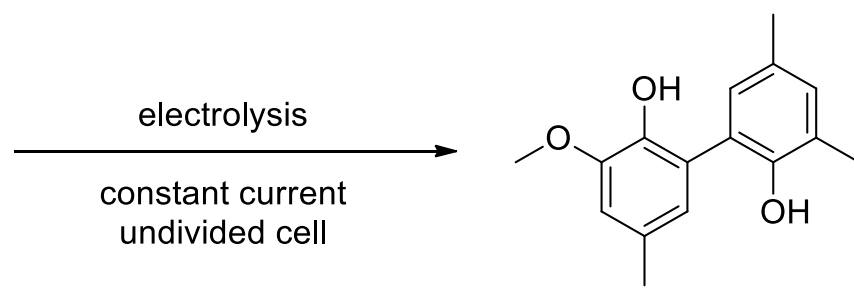

3

Scheme S 2. Anodic cross-coupling reaction of 2-methoxy-4-methylphenol 1 and 2,4-dimethylphenol 2.

\subsubsection{Screening of Supporting Electrolyte}

As first parameter, the supporting electrolyte was studied in detail. First, the already known supporting electrolyte methyl tributylammonium methylsulfate $\left(\mathrm{MeBu}_{3} \mathrm{NO}_{3} \mathrm{SOMe}\right)$ is used in the concentration of $0.9 \mathrm{~mol} / \mathrm{L}$ taken as conditions from the batch cell. Here we were able to show, that the reaction is transferred successfully to the flow cell with $10 \%$ yield (Table $S$, entry 1 ). Using non supporting electrolyte at all was not successful, because it lead to a yield of only $5 \%$ of product (Table S 2, Entry 2). Therefore, different types of supporting electrolytes and different concentration thereof were tested (Table S 2, entry 3 - 8). Nevertheless, as a low-cost alternative, sulfuric acids and acetic acid were tested as additives. In contrast to acetic acid, sulfuric acid lead to a slight increase of the yield up to $17 \%$ (Table S 2, entry 3). With the sodium salt of HFIP as supporting electrolyte the same yield was obtained (Table S 2, entry 5). However, the reaction is still more selective using $\mathrm{MeBu}_{3} \mathrm{NO}_{3} \mathrm{SOMe}$ as supporting electrolyte, which is why $\mathrm{MeBu}_{3} \mathrm{NO}_{3} \mathrm{SOMe}$ was used as supporting electrolyte in all following reactions. Subsequently, the concentration of $\mathrm{MeBu}_{3} \mathrm{NO}_{3} \mathrm{SOMe}$ was varied. Due to the smaller electrode distance, only one twentieth of the amount of supporting electrolyte is required compared to the batch process (Table S 2, Entry 7). 
Table S 2. Optimization of anodic cross-coupling reaction in $2 \mathrm{~cm} \times 6 \mathrm{~cm}$ flow cell: Variation of type and concentration of supporting electrolyte. ${ }^{a}$

\begin{tabular}{|c|c|c|c|c|c|}
\hline Entry & $\begin{array}{l}\text { Supporting } \\
\text { electrolyte }\end{array}$ & $\begin{array}{c}\text { Flow } \\
{[\mathrm{mL} / \mathrm{min}]}\end{array}$ & $\begin{array}{c}\text { Current density } \\
{\left[\mathrm{mA} / \mathrm{cm}^{2}\right]}\end{array}$ & $\begin{array}{l}\text { Spacer } \\
{[\mathrm{mm}]}\end{array}$ & $\begin{array}{l}\text { Yield }^{b} \\
{[\%]}\end{array}$ \\
\hline $1^{\mathrm{c}}$ & $\begin{array}{c}\mathrm{MeBu}_{3} \mathrm{NO}_{3} \mathrm{SOMe} \\
0.09 \mathrm{M}\end{array}$ & 0.100 & 5.0 & 0.12 & 10 \\
\hline $2^{c}$ & --- & 0.128 & 5.0 & 0.12 & 5 \\
\hline $3^{d}$ & $\begin{array}{c}\mathrm{H}_{2} \mathrm{SO}_{4} \\
0.1 \mathrm{M}\end{array}$ & 0.088 & 5.0 & 0.12 & 17 \\
\hline $4^{\mathrm{d}}$ & $\begin{array}{c}\mathrm{AcOH} \\
0.001 \mathrm{M}\end{array}$ & 0.088 & 5.0 & 0.12 & 4 \\
\hline $5^{d}$ & $\begin{array}{c}\text { NaHFIP } \\
0.1 \mathrm{M}\end{array}$ & 0.088 & 5.0 & 0.12 & 17 \\
\hline $6^{d}$ & $\begin{array}{c}\mathrm{MeBu}_{3} \mathrm{NO}_{3} \mathrm{SOMe} \\
0.01 \mathrm{M}\end{array}$ & 0.091 & 5.0 & 0.12 & 37 \\
\hline $7 \mathrm{~d}$ & $\begin{array}{c}\mathrm{MeBu}_{3} \mathrm{NO}_{3} \mathrm{SOMe} \\
0.005 \mathrm{M}\end{array}$ & 0.088 & 5.0 & 0.12 & 44 \\
\hline $8^{d}$ & $\begin{array}{c}\mathrm{MeBu}_{3} \mathrm{NO}_{3} \mathrm{SOMe}^{0.001 \mathrm{M}}\end{array}$ & 0.088 & 5.0 & 0.12 & 15 \\
\hline
\end{tabular}

aReaction conditions: 2-methoxy-4-methylphenol $1 \mathrm{c}=0.15 \mathrm{~mol} / \mathrm{L}$ and 2,4-dimethylphenol 2 $\mathrm{c}=0.45 \mathrm{~mol} / \mathrm{L}$ in HFIP $+18 \mathrm{vol} \%$ methanol, cathode: nickel, anode: BDD, electrode surface: $12 \mathrm{~cm}^{2}$, rt. ${ }^{\mathrm{b}}$ Determined by GC using an internal standard. ${ }^{\mathrm{c} A p p l i e d}$ charge: $2.0 \mathrm{~F}$. ${ }^{\mathrm{d} A p p l i e d}$ charge: $2.8 F$.

\subsubsection{Screening of Concentration and Ratio of the Starting Material}

In the next step, the concentration and the ratio of the starting materials were examined. In all these experiments, the already optimized amount of supporting electrolyte of $0.005 \mathrm{M}$ $\mathrm{MeBu}_{3} \mathrm{NO}_{3} \mathrm{SOMe}$ was used. The ratio of 2-methoxy-4-methylphenol 1 to 2,4-dimethylphenol 2 were varied from $1: 1$ to $1: 5$ (Table S 3, entry $1-5$ ), the highest yield was obtained at a ratio of $1: 3$ (Table S 3, entry 3) analogous to the batch process. The concentration of 1 was then studied over the range from $0.05 \mathrm{~mol} / \mathrm{L}$ to $0.60 \mathrm{~mol} / \mathrm{L}$, whereas in the ideal ratio of 1 to 2 was kept constant at $1: 3$ (Table S 3, entry $6-10$ ). The optimal concentrations are still $0.15 \mathrm{~mol} / \mathrm{l}$ for $\mathbf{1}$ and $0.45 \mathrm{~mol} / \mathrm{L}$ for 2 (Table S 3, entry 3). 
Table S 3. Optimization of anodic cross-coupling reaction in $2 \mathrm{~cm} \times 6 \mathrm{~cm}$ flow cell: Variation of concentration and ratio of starting material.a

\begin{tabular}{|c|c|c|c|c|c|}
\hline Entry & $\begin{array}{c}\text { Concentration } 1 \\
{[\mathrm{~mol} / \mathrm{L}]}\end{array}$ & $\begin{array}{c}\text { Concentration } 2 \\
{[\mathrm{~mol} / \mathrm{L}]}\end{array}$ & $\begin{array}{c}\text { Flow } \\
{[\mathrm{mL} / \mathrm{min}]}\end{array}$ & $\begin{array}{l}\text { Ratio } \\
A: B\end{array}$ & $\begin{array}{l}\text { Yield }^{b} \\
{[\%]}\end{array}$ \\
\hline 1 & 0.15 & 0.15 & 0.088 & $1: 1$ & 36 \\
\hline 2 & 0.15 & 0.30 & 0.088 & $1: 2$ & 36 \\
\hline 3 & 0.15 & 0.45 & 0.088 & $1: 3$ & 44 \\
\hline 4 & 0.15 & 0.60 & 0.088 & $1: 4$ & 27 \\
\hline 5 & 0.15 & 0.75 & 0.088 & $1: 5$ & 27 \\
\hline 6 & 0.05 & 0.15 & 0.263 & $1: 3$ & 31 \\
\hline 7 & 0.10 & 0.30 & 0.131 & $1: 3$ & 43 \\
\hline 8 & 0.30 & 0.90 & 0.044 & $1: 3$ & 25 \\
\hline 9 & 0.45 & 1.35 & 0.029 & $1: 3$ & 28 \\
\hline 10 & 0.60 & 1.80 & 0.022 & $1: 3$ & 20 \\
\hline
\end{tabular}

aReaction conditions: 2-methoxy-4-methylphenol $1 \mathrm{c}=0.15 \mathrm{~mol} / \mathrm{L}$ and 2,4-dimethylphenol 2 in HFIP + 18 vol \% methanol, supporting electrolyte: $\mathrm{MeBu}_{3} \mathrm{NO}_{3} \mathrm{SOMe}_{0.005} \mathrm{M}$, cathode: nickel, anode: BDD, electrode surface: $12 \mathrm{~cm}^{2}$, current density $\mathrm{j}=5 \mathrm{~mA} / \mathrm{cm}^{2}, \mathrm{rt}^{\mathrm{b}}$. Determined by GC using an internal standard. Applied charge: $2.8 F$.

\subsubsection{Screening of Current Density}

The current density was changed over the range of $5-55 \mathrm{~mA} / \mathrm{cm}^{2}$ to find the optimal current density for the anodic cross-coupling reaction (Table S 4, entry 1 - 10). When using higher current densities than $35 \mathrm{~mA} / \mathrm{cm}^{2}$ the yield decreases again. The optimal current density is $30 \mathrm{~mA} / \mathrm{cm}^{2}$ with a yield of $52 \%$ (Table S 4, entry 6). The electrode distance was then varied between $0.25 \mathrm{~mm}$, $0.50 \mathrm{~mm}$ and $0.75 \mathrm{~mm}$ (Table S 4, entry $1-3$ ). The highest yield could be achieved with the thinnest electrode distance of $0,25 \mathrm{~mm}$ and a yield of $52 \%$ (Table $\mathrm{S} 4$, entry 11 ). 
Table S 4. Optimization of anodic cross-coupling reaction in $4 \mathrm{~cm} \times 12 \mathrm{~cm}$ flow cell: Variation of current density and electrode distance at $10{ }^{\circ} \mathrm{C} .{ }^{\mathrm{a}}$

\begin{tabular}{|c|c|c|c|c|c|}
\hline Entry & $\begin{array}{c}\text { Flow } \\
{[\mathrm{mL} / \mathrm{min}]}\end{array}$ & $\begin{array}{c}\text { Current density } \\
{\left[\mathrm{mA} / \mathrm{cm}^{2}\right]}\end{array}$ & $\begin{array}{c}\text { Temperature } \\
{\left[{ }^{\circ} \mathrm{C}\right]}\end{array}$ & $\begin{array}{c}\text { Spacer } \\
{[\mathrm{mm}]}\end{array}$ & $\begin{array}{l}\text { Yield }^{b} \\
{[\%]}\end{array}$ \\
\hline $1^{c}$ & 0.351 & 5.0 & 10 & 0.25 & 48 \\
\hline 2 & 0.702 & 10.0 & 10 & 0.25 & 44 \\
\hline 3 & 1.051 & 15.0 & 10 & 0.25 & 42 \\
\hline $4^{c}$ & 1.400 & 20.0 & 10 & 0.25 & 46 \\
\hline 5 & 1.750 & 25.0 & 10 & 0.25 & 47 \\
\hline 6 & 2.100 & 30.0 & 10 & 0.25 & 52 \\
\hline 7 & 2.450 & 35.0 & 10 & 0.25 & 50 \\
\hline 8 & 2.800 & 40.0 & 10 & 0.25 & 36 \\
\hline 9 & 3.150 & 45.0 & 10 & 0.25 & 36 \\
\hline 10 & 3.500 & 50.0 & 10 & 0.25 & 29 \\
\hline 11 & 3.860 & 55.0 & 10 & 0.25 & 26 \\
\hline 12 & 2.100 & 30.0 & 10 & 0.25 & 52 \\
\hline 13 & 2.100 & 30.0 & 10 & 0.50 & 45 \\
\hline 14 & 2.100 & 30.0 & 10 & 0.75 & 37 \\
\hline
\end{tabular}

aReaction conditions: 2-methoxy-4-methylphenol $1 \mathrm{c}=0.15 \mathrm{~mol} / \mathrm{L}$ and 2,4-dimethylphenol 2

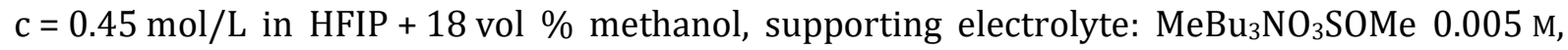
cathode: stainless steel, anode: BDD, electrode surface: $48 \mathrm{~cm}^{2}$. ${ }^{b}$ Determined by GC using an internal standard. 'Applied charge: $2.8 F$. 
Table S 5. Optimization of anodic cross-coupling reaction in $4 \mathrm{~cm} \times 12 \mathrm{~cm}$ flow cell: Variation of electrode distance. $^{a}$

$\begin{array}{cccccc}\text { Entry } & \begin{array}{c}\text { Flow } \\ {[\mathrm{mL} / \mathrm{min}]}\end{array} & \begin{array}{c}\text { Current density } \\ {\left[\mathrm{mA} / \mathrm{cm}^{2}\right]}\end{array} & \begin{array}{c}\text { Temperature } \\ {\left[{ }^{\circ} \mathrm{C}\right]}\end{array} & \begin{array}{c}\text { Spacer } \\ {[\mathrm{mm}]}\end{array} & \begin{array}{c}\text { Yieldb } \\ {[\%]}\end{array} \\ 1 & 2.100 & 30.0 & 10 & 0.25 & 52 \\ 2 & 2.100 & 30.0 & 10 & 0.50 & 45 \\ 3 & 2.100 & 30.0 & 10 & 0.75 & 37\end{array}$

aReaction conditions: 2-methoxy-4-methylphenol $1 \mathrm{c}=0.15 \mathrm{~mol} / \mathrm{L}$ and 2,4-dimethylphenol 2

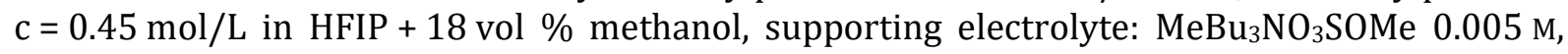
cathode: stainless steel, anode: BDD, electrode surface: $48 \mathrm{~cm}^{2}$. b Determined by GC using an internal standard. cApplied charge: $2.8 F$.

\subsubsection{Screening of Cascade Reaction}

The electrolysis conditions can also be varied in each run. Instead of a single run through a flow cell, the electrolyte is pumped through the cell in multiple runs. This results in two major advantages: First, due to a higher flow rate and a shorter dwell time respectively, the electrolyte don't heat up that strongly. Secondly, hydrogen, which is constantly evolving at the cathode as counter reaction, can be removed faster. At first the amount of charge was decreased in each run.

Therefore, the electrolyte was pumped through the cell once as reference (Figure S 8, blue), five times (Figure S 8, red) and 10 times (Figure S 8, green). Overall, it can be seen that the maximum yield achieved remains approximately 50\%. Since only a charge amount of $2.0 F$ per $\mathbf{1}$ is required for binding and a slight excess of $2.8 F$ per $\mathbf{1}$ is used, not all runs are necessary for the cascade reaction. As shown in Figure S 8 (red), the maximum yield of 50\% can be obtained with a cascade reaction of five runs after only four runs. Similarly, in the cascade reaction with 10 runs (Figure $S$ 8 , green) the electrolysis can be stopped after eight runs with a yield of $48 \%$. This has the great advantage that the overoxidation of the product can be significantly reduced. 


\section{cascade reactions}

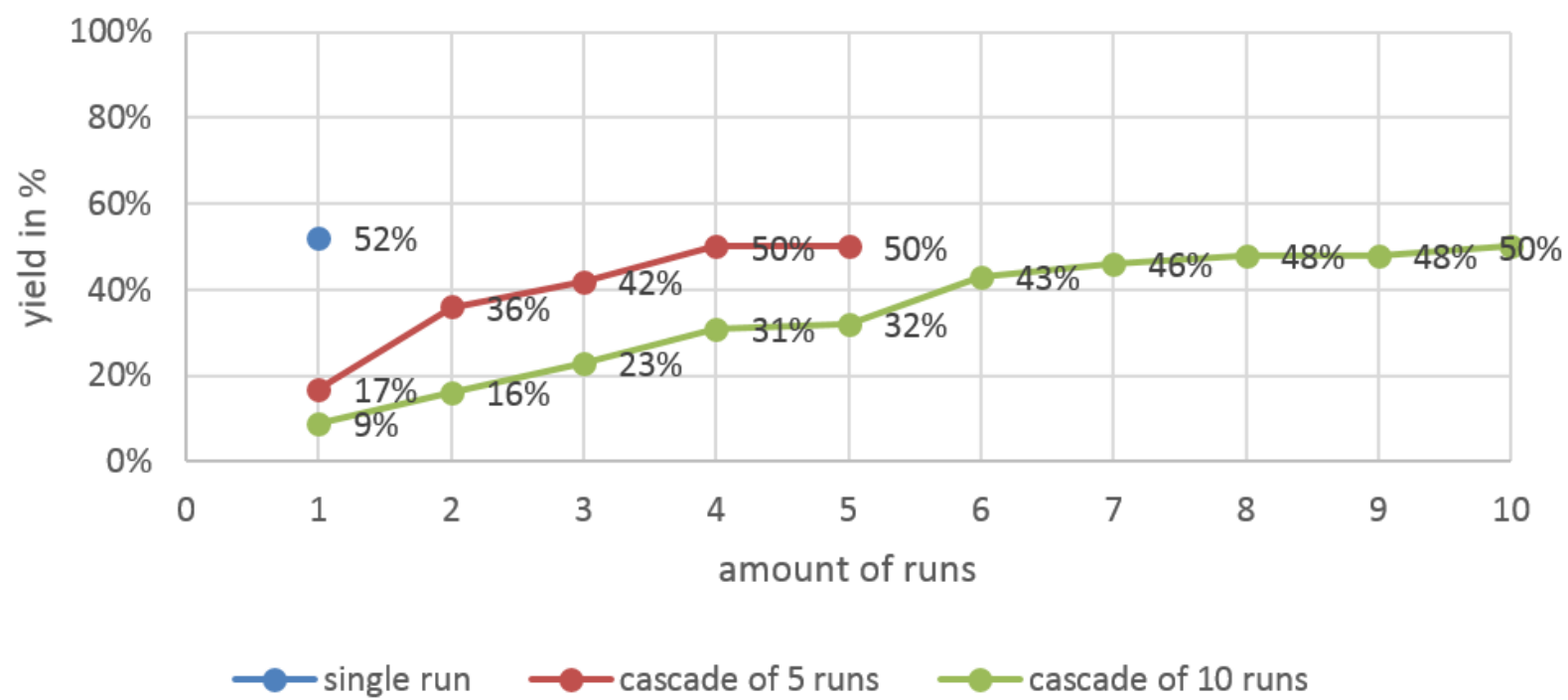

Figure S 8. Cascade reaction with a different number of runs.

aReaction conditions: 2-methoxy-4-methylphenol $1 \mathrm{c}=0.15 \mathrm{~mol} / \mathrm{L}$ and 2,4-dimethylphenol 2

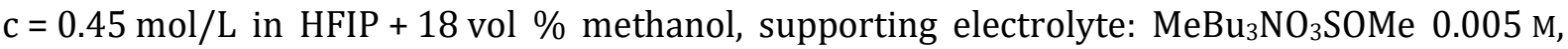
cathode: stainless steel, anode: BDD, electrode surface: $48 \mathrm{~cm}^{2}$, applied charge: $2.8 F$, current density: $30 \mathrm{~mA} / \mathrm{cm}^{2}$, Temperature: $10^{\circ} \mathrm{C}$, electrode distance: $0.25 \mathrm{~mm}$. Yields determined by GC using an internal standard. blueAmount of runs: $1, Q=2.8 F$ per run, flow rate: $2.10 \mathrm{~mL} / \mathrm{min}$. redNumber of runs: $5, Q=0.56 F$ per run, flow rate: $10.50 \mathrm{~mL} / \mathrm{min}$. green Number of runs: 10 , $\mathrm{Q}=0.28 F$ per run, flow rate: $21.00 \mathrm{~mL} / \mathrm{min}$.

\subsection{Combination 2}<smiles>COc1cccc(OC)c1O</smiles>

4
5

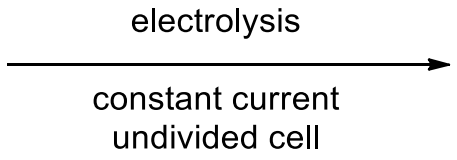

Scheme S 3. Anodic cross-coupling of 2,6-dimethoxyphenol 4 with 4-(1,1-diethylmethyl)-phenol 5.

\subsubsection{Screening of Current Density}

The current density was increased over the range of $5 \mathrm{~mA} / \mathrm{cm}^{2}-25 \mathrm{~mA} / \mathrm{cm}^{2}$. Applying higher current densities the voltage become higher than the maximum of the device. 
Table S 6. Optimization of anodic cross-coupling reaction in $4 \mathrm{~cm} \times 12 \mathrm{~cm}$ flow cell: Variation of electrode distance at $10{ }^{\circ} \mathrm{C} .{ }^{a}$

$\begin{array}{cccccc}\text { Entry } & \begin{array}{c}\text { Flow } \\ {[\mathrm{mL} / \mathrm{min}]}\end{array} & \begin{array}{c}\text { Current density } \\ {\left[\mathrm{mA} / \mathrm{cm}^{2}\right]}\end{array} & \begin{array}{c}\text { Temperature } \\ {\left[{ }^{\circ} \mathrm{C}\right]}\end{array} & \begin{array}{c}\text { Spacer } \\ {[\mathrm{mm}]}\end{array} & \begin{array}{c}\text { Yieldb } \\ {[\%]}\end{array} \\ 1^{\mathrm{c}} & 0.088 & 5.0 & \mathrm{rt} & 0.25 & 36 \\ 2 & 0.176 & 10.0 & \mathrm{rt} & 0.25 & 42 \\ 3 & 0.263 & 15.0 & \mathrm{rt} & 0.25 & 53 \\ 4 & 0.351 & 20.0 & \mathrm{rt} & 0.25 & 59 \\ & & & & & \\ 5 & 0.439 & 25.0 & \mathrm{rt} & 0.25 & 56\end{array}$

aReaction conditions: 2,6-dimethoxyphenol $4 \mathrm{c}=0.15 \mathrm{~mol} / \mathrm{L}$ and 4-tert-butylphenol 5 $\mathrm{c}=0.45 \mathrm{~mol} / \mathrm{L}$ in HFIP, supporting electrolyte: $\mathrm{MeBu}_{3} \mathrm{NO}_{3} \mathrm{SOMe} 0.005 \mathrm{M}$, cathode: nickel, anode: BDD, electrode surface: $12 \mathrm{~cm}^{2}$. b Determined by GC using an internal standard. Applied charge: $2.8 F$.

\subsubsection{Screening of Cascade Reaction}

Cascade reactions were performed for this combination (Figure S 9), as well. However, during the cascade reaction with 5 or 10 runs, strong heat development was detected in the later cycles. This resulted in a high terminal voltage during electrolysis. As a conclusion, in case of this reaction, the single run electrolysis in the $2 \mathrm{~cm} \times 6 \mathrm{~cm}$ flow cell is preferred with a maximum yield of $59 \%$. 


\section{cascade reactions}

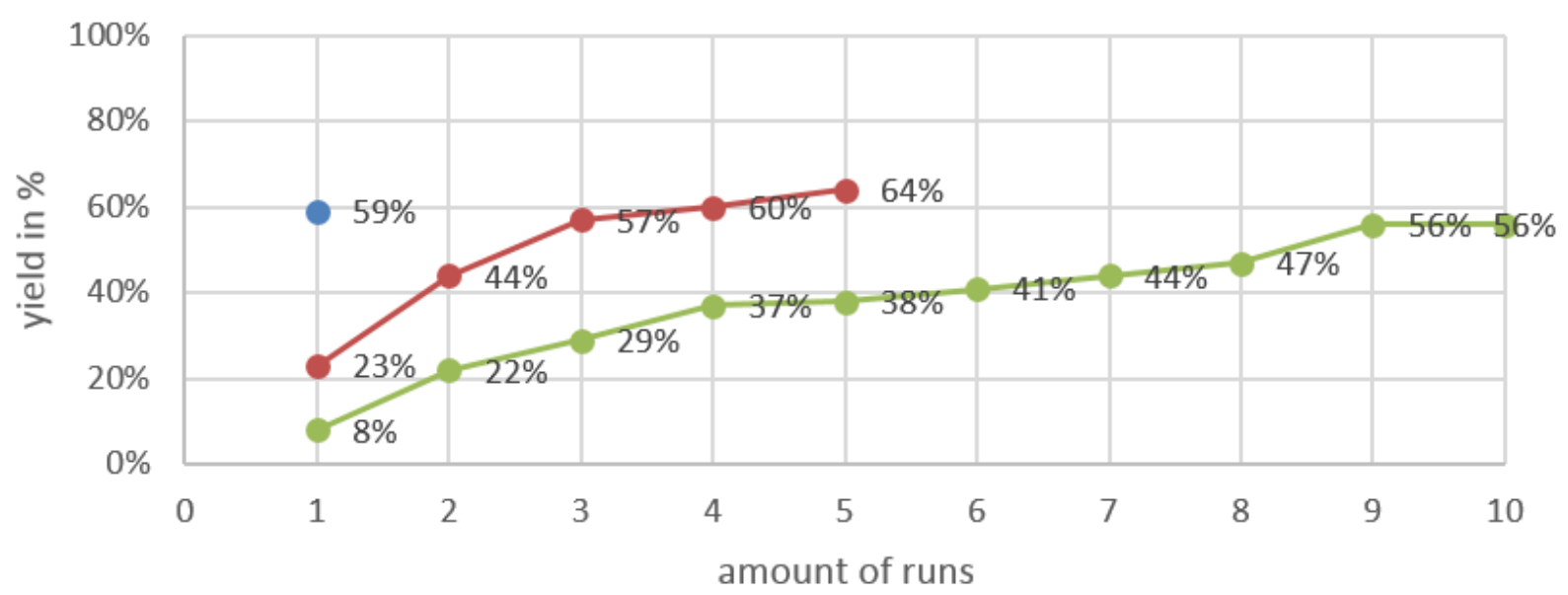

$\longrightarrow$ single run $\longrightarrow$ cascade of 5 runs $\longrightarrow$ cascade of 10 runs

Figure S 9. Cascade reaction with a different number of runs.

aReaction conditions: 2,6-dimethoxyphenol $4 \mathrm{c}=0.15 \mathrm{~mol} / \mathrm{L}$ and 4-tert-butylphenol 5 $\mathrm{c}=0.45 \mathrm{~mol} / \mathrm{L}$ in HFIP, supporting electrolyte: $\mathrm{MeBu}_{3} \mathrm{NO}_{3} \mathrm{SOMe} 0.005 \mathrm{M}$, cathode: nickel, anode: BDD, electrode surface: $12 \mathrm{~cm}^{2}$, applied charge: $2.8 F$, current density: $20 \mathrm{~mA} / \mathrm{cm}^{2}$, rt, electrode distance: $0.25 \mathrm{~mm}$. Yields determined by GC using an internal standard. blueNumber of runs: 1 , $\mathrm{Q}=2.8 \mathrm{~F}$ per run, flow rate: $0.351 \mathrm{~mL} / \mathrm{min}$. redNumber of runs: $5, \mathrm{Q}=0.56 \mathrm{~F}$ per run, flow rate: $1.41 \mathrm{~mL} / \mathrm{min}$. greenNumber of runs: $10, \mathrm{Q}=0.28 \mathrm{~F}$ per run, flow rate: $3.51 \mathrm{~mL} / \mathrm{min}$.

\subsubsection{Screening of Electrode Distance}

The cross-coupling reaction was transferred to the $4 \mathrm{~cm} \times 12 \mathrm{~cm}$ flow cell and the electrode distance was checked with different spacers of $0.25 \mathrm{~mm}, 0.50 \mathrm{~mm}$ and $0.75 \mathrm{~mm}$ (Table S 7). However, it turned out that the smallest spacer of $0.25 \mathrm{~mm}$ already provided the highest yield with $43 \%$.

Table S 7. Optimization of anodic cross-coupling reaction in $4 \mathrm{~cm} \times 12 \mathrm{~cm}$ flow cell: Variation of electrode distance at $10{ }^{\circ} \mathrm{C} .^{a}$

$\begin{array}{cccccc}\text { Entry } & \begin{array}{c}\text { Flow } \\ {[\mathrm{mL} / \mathrm{min}]}\end{array} & \begin{array}{c}\text { Current density } \\ {\left[\mathrm{mA} / \mathrm{cm}^{2}\right]}\end{array} & \begin{array}{c}\text { Temperature } \\ {\left[{ }^{\circ} \mathrm{C}\right]}\end{array} & \begin{array}{c}\text { Spacer } \\ {[\mathrm{mm}]}\end{array} & \begin{array}{c}\text { Yieldb } \\ {[\%]}\end{array} \\ 1 \mathrm{c} & 1.41 & 20.0 & 10 & 0.25 & 43\end{array}$


aReaction conditions: 2,6-dimethoxyphenol $4 \mathrm{c}=0.15 \mathrm{~mol} / \mathrm{L}$ and 4-tert-butylphenol 5 $\mathrm{c}=0.45 \mathrm{~mol} / \mathrm{L}$ in HFIP, supporting electrolyte: $\mathrm{MeBu}_{3} \mathrm{NO}_{3} \mathrm{SOMe} 0.005 \mathrm{M}$, cathode: stainless steel, anode: BDD, electrode surface: $48 \mathrm{~cm}^{2}$. ${ }^{\mathrm{b}}$ Determined by GC using an internal standard. Applied charge: $2.8 F$.

\subsubsection{Screening of Current Density}

The current density was changed over the range of $5-45 \mathrm{~mA} / \mathrm{cm}^{2}$ to find the optimal current density for the anodic cross-coupling reaction (Table S 8). At a temperature of $10^{\circ} \mathrm{C}$ the highest possible current density was $30 \mathrm{~mA} / \mathrm{cm}^{2}$ (Table S 8, entry 6). By applying higher current densities, the terminal voltage surpasses the limit of the power supply. The optimal current density is $10 \mathrm{~mA} / \mathrm{cm}^{2}$ and gives a yield of $46 \%$ (Table S 8, entry 2). At a temperature of $20^{\circ} \mathrm{C}$ the electrolysis could carry out over the range of $5-45 \mathrm{~mA} / \mathrm{cm}^{2}$ (Table S 9) with the highest yield of $49 \%$ at $15 \mathrm{~mA} / \mathrm{cm}^{2}$ (Table S 9, entry 3). 
Table S 8. Optimization of anodic cross-coupling reaction in $4 \mathrm{~cm} \times 12 \mathrm{~cm}$ flow cell: Variation of current density at $10{ }^{\circ} \mathrm{C} .{ }^{\mathrm{a}}$

$\begin{array}{cccccc}\text { Entry } & \begin{array}{c}\text { Flow } \\ {[\mathrm{mL} / \mathrm{min}]}\end{array} & \begin{array}{c}\text { Current density } \\ {\left[\mathrm{mA} / \mathrm{cm}^{2}\right]}\end{array} & \begin{array}{c}\text { Temperature } \\ {\left[{ }^{\circ} \mathrm{C}\right]}\end{array} & \begin{array}{c}\text { Spacer } \\ {[\mathrm{mm}]}\end{array} & \begin{array}{c}\text { Yield } \\ {[\%]}\end{array} \\ 1^{\mathrm{c}} & 0.351 & 5.0 & 10 & 0.25 & 40 \\ 2 & 0.702 & 10.0 & 10 & 0.25 & 46 \\ 3 & 1.051 & 15.0 & 10 & 0.25 & 39 \\ 4 \mathrm{c} & 1.400 & 20.0 & 10 & 0.25 & 43 \\ 5 & 1.750 & 25.0 & 10 & 0.25 & 37 \\ 6 & 2.100 & 30.0 & 10 & 0.25 & 40\end{array}$

aReaction conditions: 2,6-dimethoxyphenol $4 \mathrm{c}=0.15 \mathrm{~mol} / \mathrm{L}$ and 4-tert-butylphenol 5 $\mathrm{c}=0.45 \mathrm{~mol} / \mathrm{L}$ in HFIP, supporting electrolyte: $\mathrm{MeBu}_{3} \mathrm{NO}_{3} \mathrm{SOMe}_{0.005} \mathrm{M}$, cathode: stainless steel, anode: BDD, electrode surface: $48 \mathrm{~cm}^{2}$. ${ }^{\mathrm{b}}$ Determined by GC using an internal standard. Applied charge: $2.8 F$.

Table S 9. Optimization of anodic cross-coupling reaction in $4 \mathrm{~cm} \times 12 \mathrm{~cm}$ flow cell: Variation of current density at $20^{\circ} \mathrm{C} .{ }^{\mathrm{a}}$

\begin{tabular}{cccccc} 
Entry & $\begin{array}{c}\text { Flow } \\
{[\mathrm{mL} / \mathrm{min}]}\end{array}$ & $\begin{array}{c}\text { Current density } \\
{\left[\mathrm{mA} / \mathrm{cm}^{2}\right]}\end{array}$ & $\begin{array}{c}\text { Temperature } \\
{\left[{ }^{\circ} \mathrm{C}\right]}\end{array}$ & $\begin{array}{c}\text { Spacer } \\
{[\mathrm{mm}]}\end{array}$ & $\begin{array}{c}\text { Yield } \\
{[\%]}\end{array}$ \\
\hline $1^{\mathrm{c}}$ & 0.351 & 5.0 & 20 & 0.25 & 42 \\
& & & & & \\
2 & 0.702 & 10.0 & 20 & 0.25 & 37 \\
3 & 1.051 & 15.0 & 20 & 0.25 & 49
\end{tabular}




$\begin{array}{cccccc}4^{c} & 1.400 & 20.0 & 20 & 0.25 & 49 \\ 5 & 1.750 & 25.0 & 20 & 0.25 & 48 \\ & & & & & \\ 6 & 2.100 & 30.0 & 20 & 0.25 & 37 \\ 7 & 2.450 & 35.0 & 20 & 0.25 & 42 \\ 8 & 2.800 & 40.0 & 20 & 0.25 & 40 \\ 9 & 3.150 & 45.0 & 20 & 0.25 & 41\end{array}$

aReaction conditions: 2,6-dimethoxyphenol $4 \mathrm{c}=0.15 \mathrm{~mol} / \mathrm{L}$ and 4-tert-butylphenol 5 $\mathrm{c}=0.45 \mathrm{~mol} / \mathrm{L}$ in HFIP, supporting electrolyte: $\mathrm{MeBu}_{3} \mathrm{NO}_{3} \mathrm{SOMe}_{0.005} \mathrm{M}$, cathode: stainless steel, anode: BDD, electrode surface: $48 \mathrm{~cm}^{2}$. ${ }^{\mathrm{b}}$ Determined by GC using an internal standard. Applied charge: $2.8 F$.

\subsection{Combination 3}<smiles>[CH+]Oc1cccc(OC)c1O</smiles>

Scheme S 4. Anodic cross-coupling of 2,6-dimethoxyphenol 4 with methyl 3-hydroxy-2-naphthoate 7.

\subsubsection{Screening of Cascade Reaction}

Cascade reaction studies were also performed as single run, five run cascade and 10 run cascade. Again, the cascade reactions are feasible but not necessary due to the high yield in the single cycle reaction. Due to the slight excess of applied charge $(2.8 \mathrm{~F} / \mathrm{mol} 4)$, the five run cascade reaction and the 10 run cascade reaction with already be terminated after 4 runs or 8 runs, respectively. So, the resulting product is protected from overoxidation (Figure S 10). As a conclusion, in case of 
this reaction, the single run electrolysis in the $2 \mathrm{~cm} \times 6 \mathrm{~cm}$ flow cell is preferred with a maximum yield of $91 \%$.

\section{cascade reactions}

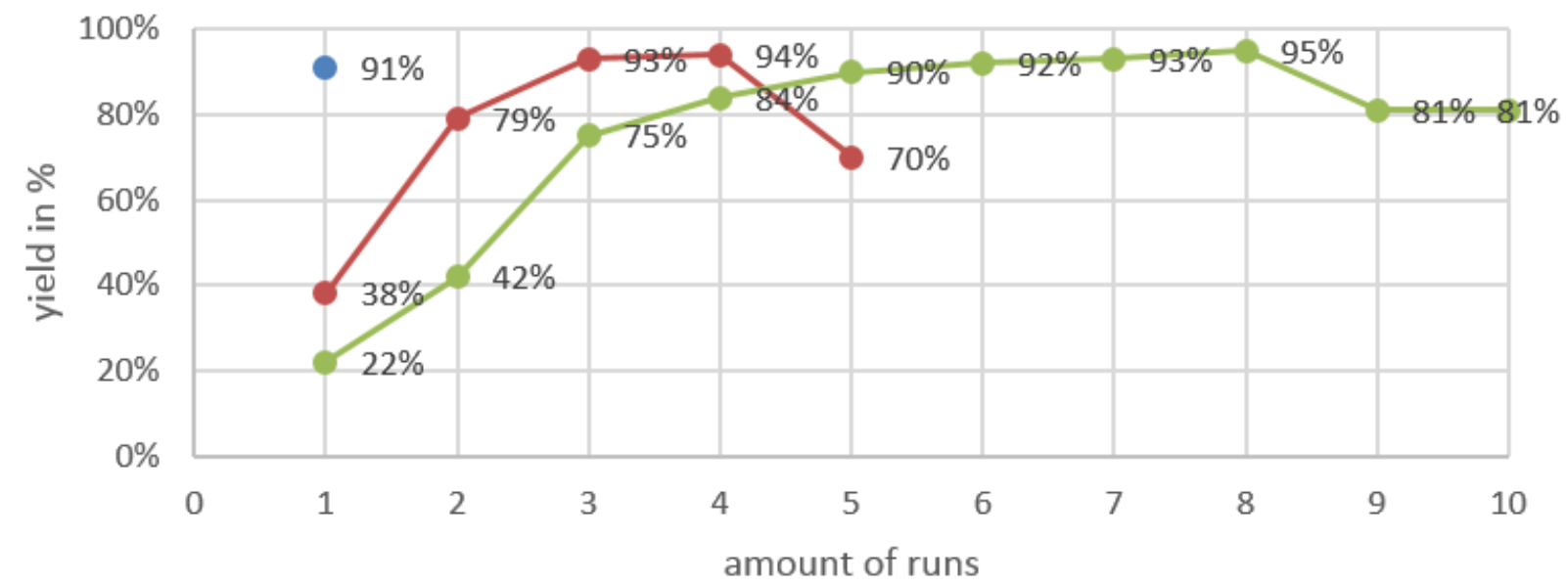

- single run cascade of 5 runs - cascade of 10 runs

Figure $S$ 10. Cascade reaction with a different number of runs.

aReaction conditions: 2,6-dimethoxyphenol $4 \mathrm{c}=0.15 \mathrm{~mol} / \mathrm{L}$ and methyl 3-hydroxy-2naphthoate $7 \mathrm{c}=0.45 \mathrm{~mol} / \mathrm{L}$ in $\mathrm{HFIP}$, supporting electrolyte: $\mathrm{MeBu}_{3} \mathrm{NO}_{3} \mathrm{SOMe} 0.005 \mathrm{M}$, cathode: nickel, anode: BDD, electrode surface: $12 \mathrm{~cm}^{2}$, applied charge: $2.8 F$, current density: $20 \mathrm{~mA} / \mathrm{cm}^{2}$, $\mathrm{rt}$, electrode distance: $0.25 \mathrm{~mm}$. Yields determined by GC using an internal standard. blueNumber of runs: $1, Q=2.8 F$ per run, flow rate: $0.351 \mathrm{~mL} / \mathrm{min}$. red Number of runs: $5, Q=0.56 F$ per run, flow rate: $1.76 \mathrm{~mL} / \mathrm{min}$. green Number of runs: $10, \mathrm{Q}=0.28 F$ per run, flow rate: $3.51 \mathrm{~mL} / \mathrm{min}$.

\subsubsection{Screening of Current Density}

The current density was changed over the range of $5-40 \mathrm{~mA} / \mathrm{cm}^{2}$ at a temperature of $10^{\circ} \mathrm{C}$ to find the optimal current density for the anodic cross-coupling reaction (Table S 10). The optimal current density is reached at $15 \mathrm{~mA} / \mathrm{cm}^{2}$ with a yield of $94 \%$ (Table S 10, entry 3). At a temperature of $20^{\circ} \mathrm{C}$ the electrolysis could carry out over the range of $5-45 \mathrm{~mA} / \mathrm{cm}^{2}$ (Table S 11) with the highest yield of $87 \%$ at $10 \mathrm{~mA} / \mathrm{cm}^{2}$ (Table S 11, entry 2). 
Table S 10. Optimization of anodic cross-coupling reaction in $4 \mathrm{~cm} \times 12 \mathrm{~cm}$ flow cell: Variation of current density at $10{ }^{\circ} \mathrm{C} .{ }^{\mathrm{a}}$

\begin{tabular}{|c|c|c|c|c|c|}
\hline Entry & $\begin{array}{c}\text { Flow } \\
{[\mathrm{mL} / \mathrm{min}]}\end{array}$ & $\begin{array}{c}\text { Current density } \\
{\left[\mathrm{mA} / \mathrm{cm}^{2}\right]}\end{array}$ & $\begin{array}{c}\text { Temperature } \\
{\left[{ }^{\circ} \mathrm{C}\right]}\end{array}$ & $\begin{array}{c}\text { Spacer } \\
{[\mathrm{mm}]}\end{array}$ & $\begin{array}{c}\text { Yield }^{\mathrm{b}} \\
{[\%]}\end{array}$ \\
\hline $1^{c}$ & 0.351 & 5.0 & 10 & 0.25 & 82 \\
\hline 2 & 0.702 & 10.0 & 10 & 0.25 & 87 \\
\hline 3 & 1.051 & 15.0 & 10 & 0.25 & 94 \\
\hline $4^{c}$ & 1.400 & 20.0 & 10 & 0.25 & 86 \\
\hline 5 & 1.750 & 25.0 & 10 & 0.25 & 88 \\
\hline 6 & 2.100 & 30.0 & 10 & 0.25 & 76 \\
\hline 7 & 2.450 & 35.0 & 20 & 0.25 & 74 \\
\hline 8 & 2.800 & 40.0 & 20 & 0.25 & 66 \\
\hline
\end{tabular}

aReaction conditions: 2,6-dimethoxyphenol $4 \mathrm{c}=0.15 \mathrm{~mol} / \mathrm{L}$ and methyl 3-hydroxy-2naphthoate $7 \mathrm{c}=0.45 \mathrm{~mol} / \mathrm{L}$ in HFIP, supporting electrolyte: $\mathrm{MeBu}_{3} \mathrm{NO}_{3} \mathrm{SOMe} 0.005 \mathrm{M}$, cathode: stainless steel, anode: BDD, electrode surface: $48 \mathrm{~cm}^{2}$. ${ }^{\text {b }}$ Determined by GC using an internal standard. Applied charge: $2.8 F$.

Table $S$ 11. Optimization of anodic cross-coupling reaction in $4 \mathrm{~cm} \times 12 \mathrm{~cm}$ flow cell: Variation of current density at $20^{\circ} \mathrm{C} .{ }^{\mathrm{a}}$

$\begin{array}{cccccc}\text { Entry } & \text { Flow } & \text { Current densit } & \text { Temperature } & \text { Spacer } & \text { Yield } \\ & {[\mathrm{mL} / \mathrm{min}]} & {\left[\mathrm{mA} / \mathrm{cm}^{2}\right]} & {\left[{ }^{\circ} \mathrm{C}\right]} & {[\mathrm{mm}]} & {[\%]}\end{array}$




\begin{tabular}{|c|c|c|c|c|}
\hline $1^{c}$ & 0.351 & 5.0 & 20 & 0.25 \\
\hline 2 & 0.702 & 10.0 & 20 & 0.25 \\
\hline 3 & 1.051 & 15.0 & 20 & 0.25 \\
\hline $4^{c}$ & 1.400 & 20.0 & 20 & 0.25 \\
\hline 5 & 1.750 & 25.0 & 20 & 0.25 \\
\hline 6 & 2.100 & 30.0 & 20 & 0.25 \\
\hline 7 & 2.450 & 35.0 & 20 & 0.25 \\
\hline 8 & 2.800 & 40.0 & 20 & 0.25 \\
\hline 9 & 3.150 & 45.0 & 20 & 0.25 \\
\hline
\end{tabular}

aReaction conditions: 2,6-dimethoxyphenol $4 \mathrm{c}=0.15 \mathrm{~mol} / \mathrm{L}$ and methyl 3-hydroxy-2naphthoate $7 \mathrm{c}=0.45 \mathrm{~mol} / \mathrm{L}$ in HFIP, supporting electrolyte: $\mathrm{MeBu}_{3} \mathrm{NO}_{3} \mathrm{SOMe} 0.005 \mathrm{M}$, cathode: stainless steel, anode: BDD, electrode surface: $48 \mathrm{~cm}^{2} .{ }^{\mathrm{b}}$ Determined by GC using an internal standard. Applied charge: $2.8 F$. 


\section{Synthesis of Non-symmetric Biphenols}

\subsection{2,2'-Dihydroxy-3-methoxy-3',5,5'-trimethylbiphenyl}

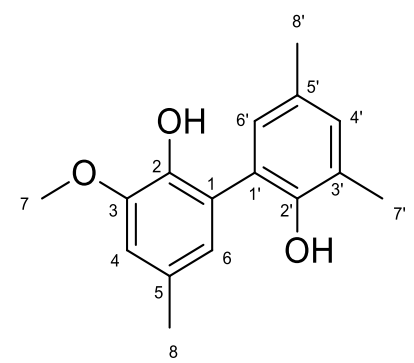

3

2-Methoxy-4-methylphenol 1 and 2,4-dimethylphenol 2 were dissolved in a solution of HFIP with 18 vol \% methanol and $\mathrm{MeBu}_{3} \mathrm{NO}_{3} \mathrm{SOMe}$. The solution was transferred into a beaker-type cell or pumped through the electrochemical flow cell. The corresponding electrochemical parameters were applied during electrolysis. After electrolysis the solvent was removed under reduced pressure, and the residue was prepared for internal standard procedure for gas chromatography measurements or purified by column chromatography (cyclohexane/ethyl acetate (4:1)). The desired product was obtained as colourless solid. mp: $120^{\circ} \mathrm{C}$ (cyclohexane/ethyl acetate $(4: 1)$ ); $\mathrm{R}_{\mathrm{f}}: 0.29$ (cyclohexane/ethyl acetate (4 : 1)); HRMS for $\mathrm{C}_{16} \mathrm{H}_{18} \mathrm{O}_{3}(\mathrm{ESI}+$ ) [M+Na+]: calc.: 281.1154, found: 281.1152 .

1H NMR (400 MHz, $\left.\mathrm{CDCl}_{3}\right): \delta[\mathrm{ppm}]=6.99-6-98\left(\mathrm{~m}, 1 \mathrm{H}, H-4^{\prime}\right), 6.93-6.92(\mathrm{~m}, 1 \mathrm{H}, H-6), 6.73(\mathrm{~m}$, 2H, $H-3^{\prime}$ ), 3.94 (s, 3H, $\left.H-2, H-6\right), 2.34$ (s, 3H, $H-7, H-8$ ), 2.30 (s, 3H, $H-8^{\prime}$ ), 2.29 (s, 3H, $H-7, H-8$ ).

Analytical data in agreement with those previously reported. ${ }^{3}$ 


\subsection{2',4-Dihydroxy-3,5-dimethoxy-5'-tert-butylbiphenyl}

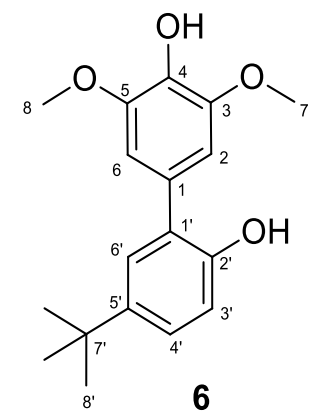

2,6-Dimethoxyphenol 4 and 4-tert-butylphenol 5 were dissolved in a solution of HFIP and $\mathrm{MeBu}_{3} \mathrm{NO}_{3} \mathrm{SOMe}$. The solution was transferred into a beaker-type cell or pumped through the electrochemical flow cell. The corresponding electrochemical parameters were applied during electrolysis. After electrolysis the solvent was removed under reduced pressure, and the residue was prepared for internal standard procedure for gas chromatography measurements or purified by column chromatography (cyclohexane/ethyl acetate $(4: 1)$ ). The desired product was obtained as colourless solid. mp: $159^{\circ} \mathrm{C}$ (cyclohexane/ethyl acetate (8 : 2)); $\mathrm{R}_{\mathrm{f}}$ : 0.23 (cyclohexane/ethyl acetate (4 : 1)); MS (FD): $m / z=302.3$ (calculated for $\mathrm{M}: \mathrm{C}_{18} \mathrm{H}_{22} \mathrm{O}_{4}=302.3$ )

${ }^{1} \mathbf{H}$ NMR (400 MHz, $\left.\left.\mathrm{CDCl}_{3}\right): \delta[\mathrm{ppm}]=7.29\left(\mathrm{dd},{ }^{3,4} J=8.5,2.5 \mathrm{~Hz}, 1 \mathrm{H}, H_{-4}\right)^{\prime}\right), 7.24\left(\mathrm{~d},{ }^{4} J=2.5 \mathrm{~Hz}, 1 \mathrm{H}\right.$, $H-6$ ), $6.94\left(\mathrm{~d}, 3 \mathrm{~J}=8.5 \mathrm{~Hz}, 1 \mathrm{H}, H-3^{\prime}\right.$ ), 6.68 (s, 2H, $H-2, H-6$ ), 3,92 (s, 6H, $H-7, H-8$ ), 1.34 (s, 9H, $H-8^{\prime}$ ).

Analytical data in agreement with those previously reported. ${ }^{4}$ 


\subsection{Methyl 3-hydroxy-4-(4'-hydroxy-3',5'-dimethoxyphenyl)-2- naphthoate}

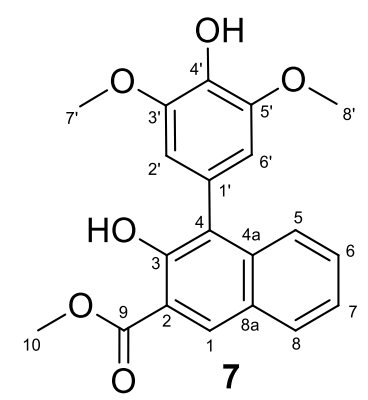

2,6-Dimethoxyphenol 4 and methyl 3-hydroxy-2-naphthoate 7 were dissolved in a solution of HFIP and $\mathrm{MeBu}_{3} \mathrm{NO}_{3} \mathrm{SOMe}$. The solution was transferred into a beaker-type cell or pumped through the electrochemical flow cell. The corresponding electrochemical parameters were applied during electrolysis. After electrolysis the solvent was removed under reduced pressure, and the residue was prepared for internal standard procedure for gas chromatography measurements or purified by column chromatography (cyclohexane/ethyl acetate (9:1)). The desired product was obtained as yellow solid. mp: $192^{\circ} \mathrm{C}$ (cyclohexane/ethyl acetate (9 : 1)); Rf: 0.24 (cyclohexane/ethyl acetate (9: 1)); MS (FD): $m / z=354.1$ (calculated for $\left.\mathrm{M}: \mathrm{C}_{20} \mathrm{H}_{18} \mathrm{O}_{6}=354.1\right)$

1H NMR (400 MHz, $\mathrm{CDCl}_{3}$ ): $\delta[\mathrm{ppm}]=10.73$ (s, 1H. $H-3$ ), 8.56 (s. 1H, H-1), 7.85 (ddd, 3,4,5 $=8.2,1.3,0.5 \mathrm{~Hz}, 1 \mathrm{H}, H-8), 7.54\left(\mathrm{dd},{ }^{3,4} \mathrm{~J}=8.6,1.3 \mathrm{~Hz}, 1 \mathrm{H}, H-5\right), 7.45$ (ddd, $3,3,4 J=8.6$, 6.7, $1.3 \mathrm{~Hz}, 1 \mathrm{H}, H-6$ ), 7.35 (ddd, ${ }^{3,3,4} \mathrm{~J}=8.2,6.7,1.3 \mathrm{~Hz}, 1 \mathrm{H}, H-7$ ), 6.62 (s, 2H, $H-2^{\prime}, H-6^{\prime}$ ), 4.05 (s, 3H, H-10), $3.89\left(\mathrm{~s}, 6 \mathrm{H}, H-7^{\prime}, H-8^{\prime}\right)$. 


\section{References}

(1) Armarego, W. L. F.; Chai, C. L. L. Purification of Laboratory Chemicals, 7th ed.;

Butterworth-Heinemann: Kidlington, Oxford, U.K., Waltham, MA, USA, 2013.

(2) Kirste, A.; Schnakenburg, G.; Stecker, F.; Fischer, A.; Waldvogel, S. R. Anodic PhenolArene Cross-Coupling Reaction on Boron-Doped Diamond Electrodes, Angew. Chem. Int. Ed. 2010, 49, 971-975.

(3) Elsler, B.; Schollmeyer, D.; Dyballa, K. M.; Franke, R.; Waldvogel, S. R. Metal- and Reagent-Free Highly Selective Anodic Cross-Coupling Reaction of Phenols, Angew. Chem. Int. Ed. 2014, 53, 5210-5213.

(4) Riehl, B.; Dyballa, K.; Franke, R.; Waldvogel, S. R. Electro-Organic Synthesis as a Sustainable Alternative for Dehydrogenative Cross-Coupling of Phenols and Naphthols, Synthesis 2016, 49, 252-259. 